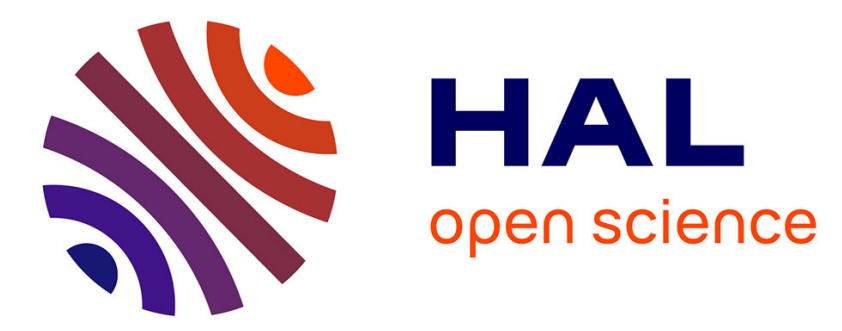

\title{
A preliminary investigation of strong-motion data from the French Antilles
}

\author{
John Douglas, Didier Bertil, Agathe Roulle, Pascal Dominique, Philippe \\ Jousset
}

\section{- To cite this version:}

John Douglas, Didier Bertil, Agathe Roulle, Pascal Dominique, Philippe Jousset. A preliminary investigation of strong-motion data from the French Antilles. Journal of Seismology, 2006, 10 (3), pp.271-299. 10.1007/s10950-006-9016-0 . hal-00557595

\section{HAL Id: hal-00557595 https: / hal-brgm.archives-ouvertes.fr/hal-00557595}

Submitted on 19 Jan 2011

HAL is a multi-disciplinary open access archive for the deposit and dissemination of scientific research documents, whether they are published or not. The documents may come from teaching and research institutions in France or abroad, or from public or private research centers.
L'archive ouverte pluridisciplinaire HAL, est destinée au dépôt et à la diffusion de documents scientifiques de niveau recherche, publiés ou non, émanant des établissements d'enseignement et de recherche français ou étrangers, des laboratoires publics ou privés. 


\title{
A preliminary investigation of strong-motion data from the
}

\section{French Antilles}

\author{
John Douglas ${ }^{1}$, Didier Bertil $^{2}$, Agathe Roullé ${ }^{1}$, Pascal Dominique ${ }^{1}$ and Philippe Jousset $^{1}$ \\ 1. BRGM, 3 avenue C. Guillemin, BP 36009, 45060 Orléans Cedex 2, France. \\ 2. BRGM, Morne Houëlmont, Route de l'Observatoire, 97113 Gourbeyre, Guadeloupe, France.
}

October 2, 2006

\begin{abstract}
Strong-motion networks have been operating in the Caribbean region since the 1970s, however, until the mid-1990s only a few analogue stations were operational and the quantity of data recorded was very low. Since the mid-1990s, digital accelerometric networks have been established on islands within the region. At present there are thought to be about 160 stations operating in this region with a handful on Cuba, 65 on the French Antilles (mainly Guadeloupe and Martinique), eight on Jamaica, 78 on Puerto Rico (plus others on adjacent islands) and four on Trinidad.

After briefly summarising the available data from the Caribbean islands, this article is mainly concerned with analysing the data that has been recorded by the networks operating on the French Antilles in terms of their distribution with respect to magnitude, source-to-site distance, focal depth and event type; site effects at certain stations; and also with respect to their predictability by ground motion estimation equations developed using data from different regions of the world. More than 300 good quality triaxial acceleration time-histories have been recorded on Guadeloupe and Martinique at a large number of stations from earthquakes with moment magnitudes larger than 4.8, however, most of the records are from considerable source-to-site distances. From the data available it is found that many of the commonly-used ground motion estimation equations for shallow crustal earthquakes poorly estimate the observed ground motions on the two islands; ground motions on Guadeloupe and Martinique have smaller amplitudes and are more variable than expected. This difference could be due to regional dependence of ground motions because of, for example, differing tectonics or crustal structures or because the ground motions so far recorded are, in general, from smaller earthquakes and greater distances than the range of applicability of the investigated equations.
\end{abstract}




\section{Introduction}

The Caribbean region is an area of moderate to high seismic hazard [e.g. Bernard and Lambert, 1988, Tanner and Shedlock, 2004]. Feuillet et al. [2002] carried out a detailed study of the recent tectonics and related seismic and volcanic activity in the Lesser Antilles. In the northern part of the arc, a series of grabens dominate with normal faults oriented in the east-west direction, perpendicular to the trench. The leading edge of the arc near Guadeloupe appears to be the site of predominantly trench-parallel extension, which gives rise to prominent normal fault and fissure systems trending mostly east-west in the outer arc. They demonstrate that there is a hazard within the arc from seismicity located on shallow faults. The most active area is shown to be between Marie-Galante and Grande-Terre, and the length of these faults suggests that earthquake magnitudes could reach or exceed 6 . This was demonstrated recently by the shallow crustal earthquake of 21st November 2004 that occurred near Guadeloupe $\left(M_{w} 6.3\right)$ and was associated with macroseismic intensity up to EMS98 VIII on the islands of Les Saintes. The southern Caribbean arc south of Martinique shows a different structure. The current deformation of the upper plate south of $15^{\circ} \mathrm{N}$ is characterised by shortening and overthrusting, without signs of arc-parallel extension. Feuillet et al. [2002] interpreted such contrasting tectonic regimes in terms of variable slip partioning. North of $16^{\circ} \mathrm{N}$ deformation along the arc is dominated by the interaction between the North American and Caribbean plates, which entails a trench parallel component of sinistral shear. Such slip vanishes south of Guadeloupe. The change in tectonic style and cessation of the parallel arc south of Dominica probably reflects the vanishing of sinistral slip partitioning.

In order to accurate assess the seismic risk in this region (and consequently derive appropriate and cost-effective strategies to mitigate this risk) it is important that the seismic hazard is well estimated. A central aspect of seismic hazard assessment is the estimation of strong ground motion expected during future earthquakes. This estimation is usually performed by assuming that future ground motions will be similar to those that have occurred during previous earthquakes. Therefore it is vital that any accelerometric data recorded within the region is carefully studied. The main purpose of this article is to summarize the accelerometric data that has been recorded by networks operating in the French Antilles (Guadeloupe and Martinique) and to present some preliminary analysis of this data in order to improve seismic hazard analysis within the region. In addition, brief descriptions of strong-motion networks operating on neighbouring Caribbean islands are given.

The geographical extent of networks in this region is quite limited because they are located on relatively small islands (there are thought to be no sea-bed strong-motion instruments operating in the area). In addition, the areas monitored by the different networks often overlap 
therefore the same earthquakes can be recorded by stations of various networks. Hence it is important that all the data from this region are considered together.

\section{Strong-motion networks on Guadeloupe}

There are currently three accelerometric networks operating on Guadeloupe. One of the networks is part of the Réseau Accélérometrique Permanent (RAP) of France and is operated by the Observatoire Volcanologique et Sismologique de Guadeloupe (Institut de Physique du Globe de Paris, IPGP), one is operated by the French Geological Survey (BRGM) and the third is operated by BRGM and IPGP under the direction of the Centre de Données Sismologiques des Antilles (CDSA).

In 1977, a small network of nine analogue (Kinemetrics SMA-1) stations was installed on Guadeloupe, however, only four usable accelerograms from one earthquake (16th March $1985, M_{w}=6.4$ at epicentral distances of more than $100 \mathrm{~km}$ ) were recorded by these stations [Bernard and Lambert, 1986, Martin, 1993]. From 1994, BRGM installed three SMACH SM-2 instruments in the Pointe-à-Pitre area to study site effects in this region. Samarcq et al. [1998] provide a summary of the early years of this network and highlight the importance of site effects at a number of stations. This network was progressively extended between 1998 and 2001. At its greatest extent it comprised 16 instruments (eight SM-2s and eight Kinemetrics K2s) and it permitted the study of site effects at 24 different sites in the region (see Le Brun et al. [2001] and Lebrun et al. [2004] who study the data with respect to microzonation of the region). This network still operates but it has been reduced to five stations; the other instruments have been transferred to Martinique or elsewhere. In 2003 and 2004, two new stations were installed in the region of Basse Terre (a K2 at Saint Claude and a Geosig GSR-24 at Gourbeyre). Detailed descriptions of the BRGM network and analyses of some early data are provided by Samarcq et al. [1999], Lebrun et al. [2000], Le Brun et al. [2001], Dominique et al. [2001] and Castro et al. [2003].

The Réseau Accéléromètrique Permanent (RAP) is the national accelerometric network of France and is currently composed of about one hundred stations throughout the seismicallyactive parts of the country. The RAP was extended to the French Antilles in 2002. The network on Guadeloupe is managed by Observatoire Volcanologique et Sismologique de Guadeloupe (IPGP) and is composed of 12 stations with Kinemetrics Episensors. This network was developed between 2002 and 2004 .

In the framework of a project to create a Centre of Seismological Data of the Antilles (CDSA), it is planned to install eight new stations in order to augment the RAP by using 
identical instruments. By July 2005, five stations were operational, of which two are installed north of the subduction arc on Saint Martin and Saint Barthélemy. For details of this network see Bengoubou-Valerius et al. [2006].

In order to increase the quantity of data used for the comparisons with the ground motion estimation equations, data from a network of five stations with Güralp CMG40-T broadband seismometers (flat response between 0.016 and $100 \mathrm{~Hz}$ ), which was set up in Bouillante on the west coast of Basse-Terre for a geothermal project [Jousset et al., 2004], are also used here even though this network was not installed for seismic hazard assessment purposes. For this study records from this network have been instrument corrected and then converted to acceleration from velocity through time-domain differentiation. Due to the sensitivity of the instruments, records are saturated when the ground motion velocity exceeds $0.5 \mathrm{cms}^{-1}$, and hence cannot be used. However, smaller ground motions are successfully recorded by the network.

Table 1 summarizes the stations that have operated, or are still operating, on Guadeloupe and Figure 1 displays their locations. Most of the stations would be classified as 'free-field' using the commonly-used criteria summarised in Douglas [2003a] since they are mainly located within instrument shelters or the ground floors of small one- or two-storey buildings.

[Figure 1 about here.]

\section{Strong-motion networks on Martinique}

Like Guadeloupe, three accelerometric networks are currently operating on Martinique. One of the networks is part of the RAP and is operated by Observatoire Volcanologique et Sismologique de la Martinique (IPGP), the Conseil Général de la Martinique (CGM) also operates a network and the third is run by BRGM.

In the mid-1980s a network comprising of two analogue stations was installed on Martinique but this did not produce any usable data [Martin, 1993]. As on Guadeloupe, in 1994, two digital instruments of type GeoSig SMACH SM-2 were installed by BRGM in order to update the analogue network. Martin [1993] describes the plan for this network. This network was complemented in November 2001 by instruments from the dense network at Pointe-à-Pitre on Guadeloupe [Dominique et al., 2001]. It is currently composed of six stations, of which five are at Fort-de-France and one is at La Trinité. The main research interest of this network is site effects.

The strong-motion network of the Conseil Général de la Martinique has been operating since 1995 (the first records were recorded on 11th January 1996). Currently the network consists of 29 stations (three of which are installed on upper stories of buildings). One station 
was removed in 2003. A detailed description of this network and the data that it has recorded is provided by Douglas et al. [2005].

Observatoire Volcanologique et Sismologique de la Martinique (IPGP) operates eight stations with Kinemetrics Episensor on Martinique within the framework of the RAP. Table 1 summarizes the stations that have operated, or are still operating, on Martinique and Figure 1 displays their locations. Like the stations of Guadeloupe, most of the stations on Martinique are classified 'free-field' stations using commonly-used criteria.

\section{Networks on other Caribbean Islands}

This section briefly outlines the accelerometric networks that are operating on other islands in the Caribbean area. Knudson [1975] provides a brief summary of the strong-motion instruments that were known to be operating in the region in December 1974.

\section{Trinidad}

The Seismic Research Unit (SRU) of the University of West Indies (UWI) installed a six accelerograph network of Kinemetrics SMA-1s in Trinidad in 1974 [Knudson, 1975]. Since 2000, it operates a four station linear array at the north of Trinidad. The stations are equipped with Kinemetrics K2 instruments with a full-scale amplitude of $2 \mathrm{~g}$. The Unit is currently conducting a preliminary analysis of the recorded data.

\section{Puerto Rico}

In the early 1970s five SMA-1s were installed on Puerto Rico [Knudson, 1975]. Currently, the Puerto Rico Strong Motion Program (PRSMP) (at the Civil Engineering Department, University of Puerto Rico) operates about 78 strong-motion instruments on Puerto Rico, with additional stations on the islands of Vieques, Culebra and Mona. Martinez-Cruzado [2003] provides a brief overview of the state of the network in 2003 but the network has recently grown significantly. PRSMP plan to install additional sensors on the British Virgin Islands and in the Dominican Republic soon. All of the instruments are at least 18 bit (Etna and Episensors), most of which (about 75\%) are dial-up instruments and ten have real-time connections. In addition, PRSMP operate eight 19-bit K2 multi-channel structural arrays on critical infrastructure (highrise buildings, bridges and dams). As yet no significant strong-motion records have been recorded. 


\section{Jamaica}

Since 1974 there has been an accelerometric network operating on Jamaica but only one earthquake (in 1978) produced a good-quality strong-motion record [Jackson, 1988]. Since roughly 2000, eight digital strong-motion instruments (seven Etnas and one K2) have been operating on Jamaica. The first significant earthquake recorded by this network was the 13th June 2005 $\left(m_{b} 5.1\right)$ event, which was recorded at three stations [Stony Hill, Mona Campus (UWI) and Runaway Bay].

\section{Other networks}

The USGS Albuquerque Seismological Laboratory has operated one strong-motion station (SJG) at San Juan on Puerto Rico since 1988 as part of the Global Seismographic Network of the Incorporated Research Institutions for Seismology (IRIS). The United States Geological Survey plan to install eight new broadband and strong-motion stations in this region as part of a tsunami warning system. There are also thought to be some strong-motion instruments operating on Cuba but little information is available. Knudson [1975] mentions a network of six SMA-1s that was installed on Barbados in 1974 by the SRU of the UWI but this is no longer operating.

\section{Site effects at strong-motion stations}

It is now well known that site effects, due to local geology or topography, can strongly amplify the surface ground motion. One of the most dramatic examples of such a phenomenon is the Michoacán earthquake of 19th September 1985, which caused more than 10,000 causalities and large economic losses in Mexico City situated more than $350 \mathrm{~km}$ from the rupture zone. The damage was essentially due to the presence of a very soft superficial clay layer [Chávez-García and Bard, 1994]. Topographic effects can also cause large ground motions [e.g. Geli et al., 1988]. Due to their volcanic origin, the French Antilles are characterized by complex topography and geology with heterogeneous volcanic deposits. They are susceptible to site effects as shown by the variation in damage on Guadeloupe caused by the earthquakes of 16th May 1851 and 29th April 1897 [Bernard and Lambert, 1988]. Site effects assessment is thus a key aspect in the general understanding of earthquake ground motion and, in a more specific way, for the realisation of efficient earthquake risk mitigation plans. In this context, site effects on the French Antilles have been extensively studied during the past ten years by the realization of seismic microzonations of the districts of Jarry-Baie Mahault, Pointe-à-Pitre and Basse-Terre on Guadeloupe [Martin et al., 1994a, Monge, 1997, Monge et al., 1998, Mompelat et al., 2003] 
and the districts of Schoelcher, Fort-de-France and Lamentin on Martinique [Martin et al., 1994b, Chassagneux et al., 1996].

Recent studies [Gagnepain-Beyneix et al., 1995, Castro et al., 2003] have demonstrated that in regions of complex geology and topography the use of local accelerometric networks can lead to a better estimation of site effects due to very local conditions and are a good complementary tool to classical microzonation [Lebrun et al., 2004]. In this framework, the strong-motion networks recently installed on Guadeloupe and Martinique are essential. For each station, it is important to know its site classification (Table 1) and the possible presence of site effects before analyzing the data. In this section, the method followed to detect the presence of site effects and to define the site class (rock or soil) for the stations of the Conseil Général de Martinique is described. The same method was used for the other networks.

Site effects evaluation is usually performed by computing spectral ratios using either earthquake records (spectral ratios relative to a reference station, or horizontal component to vertical component spectral ratios for the S-wave portion of the record) or ambient noise measurement. In this study, we use the so-called Nakamura's technique [Nakamura, 1989] based on the calculation of horizontal-to-vertical component spectral ratios $(\mathrm{H} / \mathrm{V})$ from ambient noise measurements. For a complete overview of the method, its assumptions and its limitations, the reader is referred to Lachet and Bard [1994] and Lermo and Chávez-García [1994]. It has been shown to be an efficient way to determine the dominant resonance frequency of a site [e.g. Lermo and Chávez-García, 1993, 1994, Bour et al., 1998]. However, it is important to keep in mind that $\mathrm{H} / \mathrm{V}$ spectral ratio amplitudes do not provide a good estimation of the expected amplification factor [Lachet and Bard, 1994].

For each station, a series of noise measurements were undertaken using a triaxial $5 \mathrm{~s}$ Lennartz seismometer connected to a 24 bit GeoSig recorder. The resulting spectral ratios have been calculated following the procedure described in Bour et al. [1998]. For each site, the resonance frequency of the site was obtained and the shape of the resulting $\mathrm{H} / \mathrm{V}$ spectral ratios gave important clues concerning the soil response (e.g. homogeneity of the site, importance of the site effect and possible topographic effects). The $\mathrm{H} / \mathrm{V}$ results were combined with the available topographic, geological and geotechnical data to obtain the final interpretation given in Table 2. Site classification is divided into two main groups: rock and soil. For the soil class, a complementary characterisation (stiff/medium/soft/very soft) is also estimated, if possible. The following paragraphs summarise the main results, more information can be found in Douglas et al. [2005].

The results show that nine stations (CGVI, CGBP, CGSA, CGTR, CGSJ, CGPA, CGPB, CGAT and CGDB) located on weathered tuff, alluvium or colluvium, show large site amplifi- 
cation (see Figure 2) although $\mathrm{H} / \mathrm{V}$ spectral ratio amplitudes and frequencies for two of these stations (CGBP and CGVI) are lower than the rest. In addition, CGVA, CGLO and CGDT show a site effect (Figure 3) but the results are more uncertain. At CGVA and CGLO most of the measurements were conducted on concrete slabs adjacent to the buildings, which could have affected the results obtained. At station CGDT, which is located on a crest, probably from a massive basalt lava flow as indicated by the geological map of the region, the geology and the $\mathrm{H} / \mathrm{V}$ spectral ratio are contradictory. Since the noise measurements were performed close together, it would be necessary to undertake additional measurements before final interpretation.

[Figure 2 about here.]

[Figure 3 about here.]

Eight stations are clearly located on rock (CGOB, CGDD, CGAB, CGCO, CGCA, CGDI, CGRA and CGAS). Station CGCA shows a low noise level and a very clear and flat H/V spectral ratio, hence it could be considered as a good reference station in future studies (Figure 4). The $\mathrm{H} / \mathrm{V}$ results for CGAS show a small peak at $11.5 \mathrm{~Hz}$ due to the presence of a very thin layer of alluvium. However, despite this high-frequency site effect it has been considered as a rock station since massive andesites underlie this alluvium layer. At two rock stations (CGRA and CGOB), H/V ratios present a high mean level despite a clear geology characterised by firm soils (Figure 4). This could be due to topographic effects since these stations are located on hill crests. Topographic effects are also suspected for two other stations (CGRP and CGDT) that are also located on top of hills.

[Figure 4 about here.]

Finally, the results of the last five stations (CGMB, CGFR, CGRP, CGLR and CGCP, which is colocated with CGLR) could not be interpreted. CGMB (located at the base of a dam) is characterised by heterogeneous spectral ratios, probably due to the heterogeneity of the superficial geological formations. CGFR, CGCP and CGLR seem to be affected by weak site effects. This does not agree with the known geology since CGFR is located on alluvium and the other two stations are located on pumice and alluviums. The noise measurements were made very close to the buildings and therefore cannot be considered as free-field measurements. Hence, the results are not certain and must be confirmed by an additional study. Results for CGRP, located on conglomerates at the top of a hill, show small amplification of the horizontal ground motion between 1 and $7 \mathrm{~Hz}$, which cannot be explained by the local geology. Again, 
it could correspond to a topographic effect but additional study is required before concluding this.

This study shows that sites on Martinique, and in a more general way, the volcanic Antilles, display large site-specific amplifications mainly due to superficial geology (site classifications from very soft to medium soil). The influence of topography seems to be important but additional complementary studies are required to fully understand the amplifications at some stations situated on hill crests.

\section{Summary of recorded data}

Table 3 summarises the largest earthquakes that have been recorded by the RAP, BRGM, CDSA and CGM networks on Guadeloupe and Martinique at ground response stations (records from the borehole station on Guadeloupe and from upper storeys of buildings have been excluded). This table also includes a classification of the earthquakes with respect to type (crustal, interface or intraslab). Interface earthquakes are produced at the interface of the subducting slab and generally have a reverse mechanism and intraslab earthquakes occur at depth within the subducting slab and generally have a normal mechanism [e.g. Atkinson and Boore, 2003]. Figure 5 displays the locations and focal mechanisms of these earthquakes.

In total, there are 336 high-quality records available from 24 earthquakes and 74 different stations. Figure 6 displays the distribution of data from these largest earthquakes from the strong-motion networks operating on Guadeloupe and Martinique plus the seven usable records from the Bouillante broadband network. This figure shows that all of the available data are from small and moderate-sized earthquakes $\left(M_{w} \leq 6.6\right)$ and the majority was recorded at large distances $\left(d_{h}>100 \mathrm{~km}\right)$. Consequently the vast majority of the ground motions are of low amplitudes, however, the signal-to-noise ratios for the vast majority of these records is high. For each acceleration time-history, the signal-to-noise ratio was calculated using the pre-event portion of the record as an estimate of the noise and the rest of the record as an estimate of the signal. Most of the records are from interface subduction earthquakes (91 from eleven earthquakes) and crustal earthquakes (189 from ten earthquakes of which six occurred during the Les Saintes 2004-2005 sequence) with only 56 records from three intraslab earthquakes.

The distance between Guadeloupe and Martinique (about $100 \mathrm{~km}$ ) and the relatively small size of the islands means that the distribution of data from a given earthquake with respect to distance always shows two well-separated tight distributions of records meaning that analysis of the decay of ground motions with distance is difficult due to a lack of constraint.

[Table 1 about here.] 
[Figure 5 about here.]

[Figure 6 about here.]

\section{Comparison of recorded data to existing ground motion estima- tion equations}

Equations for the estimation of the strong ground motion [e.g. Douglas, 2003a] are an important component of both probabilistic and deterministic seismic hazard assessment. At present, there are no published peer-reviewed equations for the estimation of strong ground motions based on data recorded in the Antilles [Douglas, 2004] and therefore seismic hazard assessments for this region [e.g. Tanner and Shedlock, 2004] are obliged to use equations based on data from other regions of the world. Although Motazedian and Atkinson [2005] have recently developed a ground-motion model through the stochastic simulation technique [e.g. Boore, 2003] for the prediction of motions in Puerto Rico based on data from seismological networks. In order that the seismic hazard in the Caribbean is accurately estimated it is important that the applicability of the equations developed from data from other parts of the world is assessed.

It is traditional to assess the applicability of ground motion estimation equations derived using data from one area to other regions through graphs comparing the estimated and predicted ground motions or through the use of residual plots [e.g. Boore, 2001]. Scherbaum et al. [2004] have recently developed a more quantitative method for ranking the applicability of existing ground motion estimation equations based on the values of a number of statistical quantities. They test their method on data recorded during an earthquake in eastern France (the St Dié earthquake on 22nd February 2003, $M_{w} 5.0$ ) and use only data from stations sited on rock (13 stations in total). In this article, the method is applied to data from both rock and soil sites from the earthquakes listed in Table 3.

\section{Shallow crustal earthquakes}

Observed ground motions from the selected shallow crustal earthquakes (see Table 3) have been compared with ground motions estimated by these nine sets of recent well-constrained equations: Abrahamson and Silva [1997], Ambraseys et al. [2005], Berge-Thierry et al. [2003], Boore et al. [1997], Campbell and Bozorgnia [2003], Motazedian and Atkinson [2005] ${ }^{1}$, Lussou et al. [2001], Sadigh et al. [1997] and Spudich et al. [1999]. In total 189 accelerograms have been

\footnotetext{
${ }^{1}$ This model was derived from a combination of event types, both crustal and subduction, but was shown by its authors to closely match predictions derived from crustal data from other regions hence we compare it here to data from shallow crustal earthquakes.
} 
used for this comparison. All of these equations, except Berge-Thierry et al. [2003] and Lussou et al. [2001], use $M_{w}$ therefore no magnitude scale conversion is required. For the model of Berge-Thierry et al. [2003] $M_{w}$ has been converted to $M_{s}$ by using Equation 5.3 of Ambraseys and Free [1997]. $M_{w}$ has been converted to $M_{\mathrm{JMA}}$ for use with the model of Lussou et al. [2001] by using Equation 24 of Fukushima [1996]. Ambraseys et al. [2005], Boore et al. [1997] and Spudich et al. [1999] use distance to the surface projection of the rupture $\left(d_{f}\right)$, Abrahamson and Silva [1997], Motazedian and Atkinson [2005] and Sadigh et al. [1997] use distance to the rupture $\left(d_{r}\right)$, Campbell and Bozorgnia [2003] use distance to the seismogenic zone $\left(d_{s}\right)$ and Berge-Thierry et al. [2003] and Lussou et al. [2001] use hypocentral distance $\left(d_{h}\right)$. The locations of the faults that ruptured during the chosen earthquakes have not been precisely determined therefore epicentral distance $\left(d_{e}\right)$ is used in place of $d_{f}$ and $d_{h}$ is used in place of $d_{r}$ and $d_{s}$, because there are few records from close distances these assumptions will not have an important effect. The ground-motion models are evaluated for the same mechanism as the earthquakes; for normal faulting earthquakes all the equations except Ambraseys et al. [2005], which have a coefficient for normal earthquakes, are evaluated for strike-slip faulting. BergeThierry et al. [2003], Lussou et al. [2001] and Motazedian and Atkinson [2005] do not include rupture mechanism as an explanatory variable. All equations predict the geometric mean of the horizontal motions except those of Ambraseys et al. [2005], which predict the larger horizontal component, and those of Berge-Thierry et al. [2003] and Lussou et al. [2001], who used both horizontal components. Motazedian and Atkinson [2005] develop their relations for NEHRP C sites $\left(360 \leq V_{s, 30}<760 \mathrm{~ms}^{-1}\right.$, where $V_{s, 30}$ is the average shear-wave velocity to $\left.30 \mathrm{~m}\right)$ therefore the relation is only compared to data from such sites. All stations have been classified into the site classes used within the ground-motion models, e.g. soft soil, stiff soil and rock for the model of Ambraseys et al. [2005]. The goodness-of-fit measures are computed using PGA and spectral accelerations at all periods between 0.1 and $2 \mathrm{~s}$ for which ground-motion estimates are given by the selected models, in accordance with the approach followed by Scherbaum et al. [2004].

The normalized residuals, i.e. $\epsilon_{i, j}=\left(\log y_{i}-\log y_{i, j}^{\prime}\right) / \sigma_{i, j}$ where $y_{i}$ is the observed $i$ th ground motion value, $y_{i, j}^{\prime}$ is the predicted $i$ th ground motion from the $j$ th model and $\sigma_{i, j}$ is the predicted standard deviation of the $i$ th ground motion from the $j$ th model, of all the observed ground motions are computed with respect to each of the selected ground motion models. Following the method of ranking suggested by Scherbaum et al. [2004] the following goodness-of-fit measures are computed using these sets of normalized residuals: mean (MEANNR), median (MEDNR), standard deviation (STDNR) and median LH (MEDLH), where the LH of a value $z_{0}$ is defined by: $\operatorname{LH}\left(\left|z_{0}\right|\right)=\operatorname{Erf}\left(\left|z_{0}\right| / \sqrt{2}\right.$, inf $)$ where $\operatorname{Erf}(z)$ is the error function $\frac{2}{\sqrt{\pi}} \int_{0}^{z} \exp \left(-t^{2}\right) \mathrm{d} t$. The 
results for the nine selected ground motion models are given in Table 4. The same ranking criteria as used by Scherbaum et al. [2004] have been used here, i.e.: for a model to be ranked in the lowest accepted capability class (C) requires a MEDLH of at least 0.2 , the absolute value of MEANNR and MEDNR and their standard deviations to be smaller than 0.75, and STDNR is required to be smaller than 1.5; for a model to be ranked in the intermediate capability class (B) requires a MEDLH value of at least 0.3, the absolute value of MEANNR and MEDNR and their standard deviations to be smaller than 0.5, and the STDNR to be smaller than 1.25 and; for a model to be ranked in the highest capability class (A), requires a MEDLH value of at least 0.4, the absolute value of both MEANNR and MEDNR and their standard deviations not to deviate more than 0.25 from zero and, in addition, the STDNR is required to be smaller than 1.125. Ground-motion models that do not meet these criteria are ranked in the lowest capability class (D).

Tables 4 shows that none of the chosen ground-motion models closely predicts the observed ground motions from shallow crustal earthquakes and all are ranked in class D using the criteria of Scherbaum et al. [2004], except the model of Ambraseys et al. [2005] which is ranked in class C. All models, except that of Lussou et al. [2001], overestimate the shaking (shown by negative mean and median normalized residuals) and in addition the observed grounds motions show larger variability than modelled (shown by values of the standard deviation of the normalized residuals being larger than unity). The median ground motions are well estimated by the model of Lussou et al. [2001] (shown by mean and median normalized residuals close to zero) but the observed motions are more variable than the model predicts. The model of Motazedian and Atkinson [2005] is the first that uses data from the Caribbean region (specifically Puerto Rico), however, it does not estimate well the observed ground motions on Guadeloupe and Martinique. This could be because the geology and tectonics of Puerto Rico are not comparable to those of the French Antilles, in particular Puerto Rico is not a volcanic island.

One reason that could explain these findings is that the data used for the validation procedure mainly comes from smaller events and from greater distances than the data used to derive the selected models. Ground motions from small and moderate events display faster decay with distance, higher dependence on magnitude and greater variability than ground motions from larger earthquakes [e.g. Douglas, 2003b]. In order to test this possible reason for the observed poor match between observations and predictions, a subset of data (45 records) was selected from earthquakes with $M_{w}>5.5$ and distances less than $100 \mathrm{~km}$ (i.e. data within the range of validity of most of the ground-motion models considered) and the analysis repeated. The results obtained show generally smaller absolute values (but still generally negative) of the median and mean normalized residuals, showing that the average ground motions are better 
predicted, but the standard deviations of the normalized residuals remain high.

This preliminary analysis suggests that ground motions from earthquakes in the Antilles seem to be weaker than those in California and seismically active parts of Europe and the Middle East. One possible reason for lower average ground motions is that most of the data used here comes from normal faulting earthquakes, which generally show slightly weaker ground motions than those from strike-slip and reverse earthquakes [e.g. Bommer et al., 2003] and this difference is not explicitly modelled by any of the chosen ground-motion models except for Ambraseys et al. [2005]. However, this is unlikely to be a significant factor since the effect of style-of-faulting is generally quite small [Bommer et al., 2003].

Other possible reasons for the lower ground motions from earthquakes in the Antilles compared with those in other regions are differences in average focal depth between the regions, lower stress drops and faster attenuation. Castro et al. [2003] estimate that $Q=64.5 f^{0.4}$ in the Antilles region, which they find is lower (i.e. attenuation is faster) than the $Q$ obtained for other regions close to subduction zones (Oaxaca and Guerrero, Mexico). Atkinson and Silva [2000] find that $Q=180 f^{0.45}$ in California, which again is higher (i.e. attenuation is slower) than in the Antilles. Castro et al. [2003] suggest that the fast attenuation in the Antilles is due to complex source-station paths that sample low-velocity and high-attenuation zones in the crust and mantle wedge associated with arc magmatic systems.

[Table 2 about here.]

Figure 7 shows the normalized residuals for PGA for the equation of Ambraseys et al. [2005] with respect to epicentral distance and $M_{w}$. It shows that the model of Ambraseys et al. [2005] predicts the median PGA reasonably well at all distances from 20 to $500 \mathrm{~km}$ (note that the model of Ambraseys et al. [2005] was derived using data from distances less than or equal to $100 \mathrm{~km}$ ) and for all magnitudes greater than about 5.5. PGA values from earthquakes with $M_{w}<5.5$ are on average overestimated by the equation of Ambraseys et al. [2005]. For the rest of the article the model of Ambraseys et al. [2005] is used since it seems to be the most appropriate available model for ground-motion estimation for shallow crustal earthquakes in this region.

[Figure 7 about here.]

\section{Ground-motion variability due to source effects}

An interesting example of the variability in ground motions is the differences between the accelerograms recorded during the Les Saintes aftershocks at 13:37 and 18:53 on 21st November 
2004, which had similar magnitudes (5.3 and 5.4 respectively) and occurred at similar locations. Ground motions recorded during the event at 13:37 are, generally, much smaller than those observed during the 18:53 aftershock. This cannot be explained by repeatable site effects, which should be similar at the same stations during both earthquakes [ground-motion amplitudes are too small $(<0.15 \mathrm{~g})$ for nonlinear soil behaviour, which could cause inter-event site amplification variation, to be an issue]. In comparison with the ground-motion model of Ambraseys et al. [2005] the motions from the 13:37 aftershock are smaller than expected while those from the 18:53 event are larger than expected.

Figure 8(a) shows the ratios between the spectral accelerations recorded during the 13:37 event to those recorded during the 18:53 event for the ten common stations. To minimize the minor differences in distance and magnitude between records from the two events, the equations of Ambraseys et al. [2005] were used to adjust the observed spectral accelerations to a common distance and magnitude (the maximum correction factor is roughly 1.5). For the three closest stations (Belfond Saint-Claude, Aérodrome Baillif and Ecole Pigeon) the difference between the earthquakes is a factor of about ten at all examined periods. As the source-to-site distance increases the difference between the ground motions in the two earthquakes decreases; this is expected since source effects are reduced in importance as waves propagate due to scattering and attenuation.

The eight common stations that recorded much higher ground motions during the 18:53 aftershock than during the 13:37 event are all located on Guadeloupe (to the north of the epicentre) whereas the two common stations on Martinique (to the south of the epicentre) recorded similar or lower ground motions during the 18:53 event. Therefore one possible explanation for the differences in ground motions in the two earthquakes is directivity [e.g. Somerville, 2003], i.e. the fault ruptured away from Guadeloupe (and towards Martinique) during the 13:37 event (explaining the lower than expected motions) and towards Guadeloupe (and away from Martinique) during the 18:53 earthquake (the published focal mechanisms of these two events show strikes roughly aligned in the directions of the two islands). Directivity effects, however, are believed to only affect a narrow band (roughly $T_{\text {dir }} / 1.5<T<1.5 T_{\text {dir }}$, where $T_{\text {dir }}$ is a magnitude-dependent pulse period) of intermediate- and long-period response spectral ordinates for stations close to moderate and large earthquakes $\left(M_{w}>6\right)$ [Somerville, 2003] rather than the whole period range at all distances from relatively small earthquakes. Therefore it is more probable that other source effects [e.g. differing stress drops, the slightly different focal mechanisms or directionality due to focussing of waves along the path aligned with the rupture propagation direction (J. J. Bommer, written communication, 2005)] are the cause of the observed differences in ground motions. It is possible that the $M_{w}$ of the $13: 37$ event 
is overestimated or the $M_{w}$ of the 18:53 event is underestimated but this is thought unlikely since the $M_{w}$ values given by Harvard CMT for these events are consistent with reported $M_{s}$ and $m_{b}$ values.

For comparison the same type of analysis was conducted for two other Les Saintes aftershocks with similar magnitudes: those of 27th November 2004 at 23:44 and 2nd December 2004 at 14:47 with $M_{w} 4.9$ and 5.0 respectively. Again, differences in ground motions due to slightly differing magnitudes and distances were corrected using the ground-motion model of Ambraseys et al. [2005]. The results of this analysis are shown in Figure 8(b). This figure shows that, unlike for the aftershocks discussed above, the ground motions during these two events were generally similar (most of the spectral ratios vary between 0.5 and 2), suggesting that the two sources were also comparable.

[Figure 8 about here.]

\section{Subduction earthquakes}

Recorded ground motions from the selected subduction earthquakes (see Table 3) have been compared with ground motions estimated by these three sets of equations: Atkinson and Boore [2003], Crouse [1991] and Youngs et al. [1997]. Atkinson and Boore [2003] have combined the datasets of Crouse [1991] and Youngs et al. [1997] and also have added much additional data therefore the equations of Atkinson and Boore [2003] could be thought to have superseded the equations of Crouse [1991] and Youngs et al. [1997]. The equations of Crouse [1991] and Youngs et al. [1997] have been included here since they have often been used for seismic hazard assessments of the Antilles and therefore it is important to check their validity. All three equations use $M_{w}$. Hypocentral distance has been used as the distance metric for all comparisons. Both horizontal components have been used by Crouse [1991], the geometric mean of the two horizontal components have been used by Youngs et al. [1997] and Atkinson and Boore [2003]. Crouse [1991] only uses data from stiff soil sites therefore comparison has been made here only for data from such sites. The equations of Atkinson and Boore [2003] and Youngs et al. [1997] model differences between ground motions from interface and intraslab earthquakes whereas the model of Crouse [1991] does not.

The same analysis procedure was followed for the ground motions from the subduction earthquakes as for the data of the shallow crustal earthquakes. The results for the three selected models are given in Table 5. The analysis shows that the model of Youngs et al. [1997] is quite successful at predicting the ground motions on Guadeloupe and Martinique although it slightly overestimates the shaking. Surprisingly, the recent model developed by Atkinson and Boore [2003] through sophisticated analysis of a much larger dataset, including all the data 
of Crouse [1991] and Youngs et al. [1997] plus additional records, greatly underpredicts the observed ground motions and also the variability of motions. The reason for this difference is thought to be that Atkinson and Boore [2003] mainly concentrated on developing a groundmotion model for predicting the response spectra from earthquakes much larger than those in the dataset used here. In addition, Atkinson and Boore [2003] excluded data from large distances partly to avoid bias due to non-triggering instruments, whereas Crouse [1991] and Youngs et al. [1997] did not, which will lead to lower predicted motions at great distances than when such a truncation is not applied [e.g. Joyner and Boore, 1981].

[Table 3 about here.]

Figure 9 shows the normalized residuals for PGA for the equation of Youngs et al. [1997] with respect to hypocentral distance and $M_{w}$ for the two types of subduction earthquake (intraslab and interface). It shows that the model of Youngs et al. [1997] slightly overpredicts the median PGA at all distances from 50 to $300 \mathrm{~km}$ and for all magnitudes from 4.8 to 5.8 for both types of event.

[Figure 9 about here.]

\section{High-amplitude ground motions recorded at the station TDBA}

Since its installation in November 2004, the station TDBA on Guadeloupe has regularly experienced much higher than expected ground motions given the magnitudes and distances of the causative earthquakes. The station is located in the hamlet of Petites Anses, on Les Saintes, within the fire station, which is a small one-storey building. This area was the most affected by the Les Saintes earthquake of 21st November 2004 .

On 12th December 2004, an earthquake of $M_{L} 2.9$ that occurred at a depth of $3 \mathrm{~km}$ at an epicentral distance of $3 \mathrm{~km}$ caused a horizontal PGA of nearly $0.3 \mathrm{~g}$ at TDBA. This large PGA is similar to the large PGA values from small earthquakes reported by Hanks and Johnson [1976] and can be attributed to the short source-to-site distance.

Another example of particular high ground motions recorded at TDBA is the record from the 14th February $2005 M_{w} 5.8$ normal-faulting earthquake that occurred at a focal depth of $12 \mathrm{~km}$ at an epicentral distance of $8 \mathrm{~km}$ (hypocentral distance of $14 \mathrm{~km}$ ). This strong-motion record has been processed with a high-pass filter with a cut-off frequency of $0.125 \mathrm{~Hz}$, which was chosen by an examination of the signal-to-noise Fourier spectral ratio. The horizontal PGA of this record is about $0.7 \mathrm{~g}$, which is over four times that estimated by the ground-motion model of Ambraseys et al. [2005] for that distance from such a sized normal-faulting earthquake and it is thought to be the highest acceleration ever recorded in the Antilles (Figure 10). The elastic 
response spectrum of this record is also up to a factor of seven times larger than the spectrum estimated by the model of Ambraseys et al. [2005], see Figure 11. The record is similarly underestimated by other ground-motion models for shallow crustal earthquakes. Table 6 lists a number of strong-motion parameters of this record and compares them with predicted values of recent ground-motion models for a rock site. This comparison shows that all the amplitude measures are much higher than expected whereas the relative significant duration is almost identical to that expected, thereby showing importance of the point raised by Bommer et al. [2004] that extreme records with respect to one characteristic (for this record, amplitude) are unlikely to be extreme in another respect (here, duration).

[Figure 10 about here.]

[Figure 11 about here.]

[Table 4 about here.]

Possible reasons for the large amplitude ground motions include directivity and site effects. Site effects are unlikely to be responsible since $\mathrm{H} / \mathrm{V}$ spectral ratio measurements conducted by CETE Méditerranée for this station show low-frequency $(2 \mathrm{~Hz})$ amplification (E. Bertrand, personal communication, 2005) whereas as shown above high-frequency ground motions from this station are also much higher than expected. In fact, the record was significantly higher than expected over the entire period range of engineering interest. The high-amplitude motions recorded at this station are likely due to proximity to the causative fault, which is not fully accounted for here in the comparison with ground-motion models because of the use of pointsource distance measures, and possibly rupture towards the site during the 14th February 2005 earthquake (directivity effects). Directivity effects could perhaps explain the large long-period spectral ordinates of the EW component (probably roughly the fault-perpendicular component) but not on the NS component. At present the causative fault of this earthquake has not be identified nor has any strong-motion modelling been attempted therefore it is not currently possible to confirm this suggestion.

\section{Conclusions}

This article has summarised current strong-motion observation capabilities within the Caribbean and in particular it has summarised and presented a preliminary analysis of the available data from the French Antilles. The strong-motion networks on the French Antilles have been greatly developed in the last decade but the distribution of stations in the eastern Caribbean is highly 
inhomogeneous. This inhomenegenity is a particular concern because of the complex geological and tectonic context in this region with transform zones in the north (close to Puerto Rico) and the south (close to Venezuela) and a long subduction arc in the east.

In total, 336 records from 24 moderate earthquakes $\left(4.8 \leq M_{w} \leq 6.6\right)$ that occurred in the past ten years are exploitable from the networks on Guadeloupe and Martinique (from 74 different stations). However, apart from those records from the Les Saintes sequence of late 2004 and early 2005, most of the available records are from hypocentral distances greater than $100 \mathrm{~km}$. There are only 56 records from three intraslab earthquakes.

It is possible that ground motion estimation equations developed for other regions (California, Europe and the Middle East, Japan and Puerto Rico) may not be applicable for the estimation of ground motions for sites on the French Antilles. However, for shallow crustal earthquakes, the ground-motion model of Ambraseys et al. [2005] was shown to be the most appropriate of those tested and for subduction earthquakes, predictions from the model of Youngs et al. [1997] gave the closest match to observed ground motions. The ground-motion model of Motazedian and Atkinson [2005], which was developed for Puerto Rico, does not provide good estimates of ground motions on the French Antilles.

Because the strong-motion networks in this region have only been operating for about a decade there is insufficient data of engineering significance to develop region-specific empirical ground motion estimation equations. Therefore one possible way of improving the estimation of ground motion in the French Antilles is to use the hybrid empirical ground motion estimation method of Campbell [2003, 2004], which has been developed further by Scherbaum et al. [2005] and applied by Douglas et al. [2006] to southern Spain and southern Norway. The results of Castro et al. [2003] on site effects and crustal attenuation would be useful for this purpose.

Data from the Les Saintes sequence shows that source effects can be at least as important as site effects in explaining the variability in ground motions. Two aftershocks with similar magnitudes, focal mechanisms and locations caused ground motions at some stations on Guadeloupe that were more than ten times higher in one earthquake than in the other. The cause of this variability should be investigated further. In addition, some near-field records from this sequence are greatly underestimated by ground-motion models over a wide frequency band, probably due to the proximity to the source and, possibly, directivity.

\section{Acknowledgements}

This study was funded by research and public service BRGM projects. The strong-motion networks on Guadeloupe are operated by BRGM and the Institut de Physique du Globe de 
Paris (IPGP), which is under the aegis of the Réseau Accélérometrique Permanent (RAP) of France. The strong-motion networks on Martinique are operated by BRGM, Conseil Général de la Martinique and IPGP for the RAP. The RAP data centre is based at Laboratoire de Géophysique Interne et de Tectonophysique, Grenoble. We are very grateful to the personnel of these organisations for operating the stations and providing us with the data, without which this study would have been impossible. We also thank B. Naigre for permission to publish this article using the data of the Conseil Général de la Martinique and for permission to consult the geotechnical database realized by GEOTER (Report GTR/CGM/0101-138). C. Maurin undertook the microtremor measurements analysed here, R. Porcella sent us a copy of Knudson [1975], P. M. Smit sent us a copy of Samarcq et al. [1998], F. Scherbaum answered our questions about the method used in Scherbaum et al. [2004], R. Robertson provided some useful information on the strong-motion network on Trinidad, W. Aspinall gave us some useful information on strong-motion networks in the region, M. D. Wiggins-Grandison provided useful information on the network operating on Jamaica and J. Clinton brought us up-to-date with the current strong-motion network on Puerto Rico. We thank J. J. Bommer and two anonymous reviewers for their valuable comments that improved the article. Figures 1 and 5 were created using GMT [Wessel and Smith, 1991].

\section{References}

N. A. Abrahamson and W. J. Silva. Empirical ground motion models. Technical report, 1996. Report to Brookhaven National Laboratory. Cited in Stewart et al. [2001].

N. A. Abrahamson and W. J. Silva. Empirical response spectral attenuation relations for shallow crustal earthquakes. Seismological Research Letters, 68(1):94-127, Jan/Feb 1997.

N. N. Ambraseys, J. Douglas, S. K. Sarma, and P. M. Smit. Equations for the estimation of strong ground motions from shallow crustal earthquakes using data from Europe and the Middle East: Horizontal peak ground acceleration and spectral acceleration. Bulletin of Earthquake Engineering, 3(1):1-53, 2005.

N. N. Ambraseys and M. W. Free. Surface-wave magnitude calibration for European region earthquakes. Journal of Earthquake Engineering, 1(1):1-22, 1997.

G. M. Atkinson and D. M. Boore. Empirical ground-motion relations for subduction zone earthquakes and their application to Cascadia and other regions. Bulletin of the Seismological Society of America, 93(4):1703-1729, 2003. 
G. M. Atkinson and W. Silva. Stochastic modeling of California ground motion. Bulletin of the Seismological Society of America, 90(2):255-274, Apr 2000.

M. Bengoubou-Valerius, D. Bertil, S. Bazin, A. Bosson, and F. Beauducel. CDSA: New seismological data center for French West Indies. Seismological Research Letters, 2006. In preparation.

C. Berge-Thierry, F. Cotton, O. Scotti, D.-A. Griot-Pommera, and Y. Fukushima. New empirical response spectral attenuation laws for moderate European earthquakes. Journal of Earthquake Engineering, 7(2):193-222, 2003.

P. Bernard and J. Lambert. Macrosismicité des Petites Antilles: Compte rendu des effets du séisme du 16 mars 1985 et exploitation des accélérogrammes. Technical Report 86 SGN 003 GEG, BRGM, France, Jan 1986. In French.

P. Bernard and J. Lambert. Subduction and seismic hazard in the northern Lesser Antilles: Revision of the historical seismicity. Bulletin of the Seismological Society of America, 78(6): 1965-1983, Dec 1988.

J. J. Bommer, N. A. Abrahamson, F. O. Strasser, A. Pecker, P.-Y. Bard, H. Bungum, F. Cotton, D. Fäh, F. Sabetta, F. Scherbaum, and J. Studer. The challenge of defining upper bounds on earthquake ground motions. Seismological Research Letters, 75(1):82-95, 2004.

J. J. Bommer, J. Douglas, and F. O. Strasser. Style-of-faulting in ground-motion prediction equations. Bulletin of Earthquake Engineering, 1(2):171-203, 2003.

D. M. Boore. Comparisons of ground motions from the 1999 Chi-Chi earthquake with empirical predictions largely based on data from California. Bulletin of the Seismological Society of America, 91(5):1212-1217, Oct 2001.

D. M. Boore. Simulation of ground motion using the stochastic method. Pure and Applied Geophysics, 160:635-676, 2003.

D. M. Boore, W. B. Joyner, and T. E. Fumal. Equations for estimating horizontal response spectra and peak acceleration from western North American earthquakes: A summary of recent work. Seismological Research Letters, 68(1):128-153, Jan/Feb 1997.

M. Bour, D. Fouissac, P. Dominique, and C. Martin. On the use of microtremor recordings in seismic microzonation. Soil Dynamics and Earthquake Engineering, 17:465-474, 1998.

BRGM. La Banque du Sous-Sol. On Internet at: infoterre.brgm.fr, 2005. 
K. W. Campbell. Empirical near-source attenuation relationships for horizontal and vertical components of peak ground acceleration, peak ground velocity, and pseudo-absolute acceleration response spectra. Seismological Research Letters, 68(1):154-179, Jan/Feb 1997.

K. W. Campbell. Prediction of strong ground motion using the hybrid empirical method and its use in the development of ground-motion (attenuation) relations in eastern North America. Bulletin of the Seismological Society of America, 93(3):1012-1033, 2003.

K. W. Campbell. Erratum to 'Prediction of strong ground motion using the hybrid empirical method and its use in the development of ground-motion (attenuation) relations in eastern North America'. Bulletin of the Seismological Society of America, 94(6):2418, 2004.

K. W. Campbell and Y. Bozorgnia. Updated near-source ground-motion (attenuation) relations for the horizontal and vertical components of peak ground acceleration and acceleration response spectra. Bulletin of the Seismological Society of America, 93(1):314-331, 2003.

R. R. Castro, H. Fabriol, M. Bour, and B. Le Brun. Attenuation and site effects in the region of Guadeloupe, Lesser Antilles. Bulletin of the Seismological Society of America, 93(2): 612-626, Apr 2003.

D. Chassagneux, C. Martin, O. Monge, F. Samarcq, and O. Sedan. Microzonage sismique des communes de Schoelcher, Fort-de-France et Lamentin: Effets de site et liquéfaction. Final report R 39186, BRGM, France, 1996. In French.

F. J. Chávez-García and P.-Y. Bard. Site effects in Mexico City eight years after the September 1985 Michoacan earthquakes. Soil Dynamics and Earthquake Engineering, 13:229-247, 1994.

C. B. Crouse. Ground-motion attenuation equations for earthquakes on the Cascadia subduction zones. Earthquake Spectra, 7(2):201-236, 1991.

P. Dominique, P. Sabourault, and B. Le Brun. Réseau Accéléromètrique Permanent RAP Année 2001 - Rapport complémentaire. Final report BRGM/RP51406-FR, BRGM, France, 2001. In French.

J. Douglas. Earthquake ground motion estimation using strong-motion records: A review of equations for the estimation of peak ground acceleration and response spectral ordinates. Earth-Science Reviews, 61(1-2):43-104, 2003a.

J. Douglas. A note on the use of strong-motion data from small magnitude earthquakes for empirical ground motion estimation. In Skopje Earthquake 40 Years of European Earthquake Engineering (SE-4OEEE), Aug 2003b. 
J. Douglas. Ground motion estimation equations 1964-2003: Reissue of ESEE Report No. 01-1: 'A comprehensive worldwide summary of strong-motion attenuation relationships for peak ground acceleration and spectral ordinates (1969 to 2000)' with corrections and additions. Technical Report 04-001-SM, Department of Civil and Environmental Engineering; Imperial College of Science, Technology and Medicine; London; U.K., Jan. 2004. On Internet at: http://www3.imperial.ac.uk/civilengineering/research/researchnewsandreports/researchreports.

J. Douglas, H. Bungum, and F. Scherbaum. Ground-motion prediction equations for southern Spain and southern Norway obtained using the composite model perspective. Journal of Earthquake Engineering, 10(1):33-72, 2006.

J. Douglas, A. Roullé, P. Dominique, C. Maurin, and F. Dunand. Traitement des données accélérometriques du Conseil Général de la Martinique. Final report RP-53906-FR, BRGM, Orléans, France, May 2005. In French. On Internet at: http://www.brgm.fr/publication/rechRapportSP.jsp .

N. Feuillet, I. Manighetti, P. Tapponnier, and E. Jacques. Arc parallel extension and localization of volcanic complexes in Guadeloupe, Lesser Antilles. Journal of Geophysical Research, 107(B12):2331, 2002. doi:10.1029/2001JB000308.

C. Frohlich and K. D. Apperson. Earthquake focal mechanisms, moment tensors, and the consistency of seismic activity near plate boundaries. Tectonics, 11(2):279-296, Apr 1992.

Y. Fukushima. Scaling relations for strong ground motion prediction models with $M^{2}$ terms. Bulletin of the Seismological Society of America, 86(2):329-336, 1996.

J. Gagnepain-Beyneix, J. C. Lepine, A. Nercessian, and A. Hirn. Experimental study of site effects in the Fort-de-France area (Martinique island). Bulletin of the Seismological Society of America, 85:478-495, 1995.

L. Geli, P.-Y. Bard, and B. Jullien. The effect of topography on earthquake ground motion: A review and new results. Bulletin of the Seismological Society of America, 78(1):42-63, Feb 1988.

T. C. Hanks and D. A. Johnson. Geophysical assessment of peak accelerations. Bulletin of the Seismological Society of America, 66(3):959-968, Jun 1976.

T. A. Jackson. The development and present status of seismic research work in Jamaica, West Indies. Physics of the Earth and Planetary Interiors, 58(1):1-8, 1988. 
P. Jousset, S. Bès de Berc, H. Fabriol, and B. Chouet. Monitoring and exploration of geothermal fields using broadband seismology: Application to Bouillante, Guadeloupe. In IAVCEI General Assembly, Pucon, Chile, 14th-19th November, 2004. Symposium 8. 508b-pf-126. Abstract only.

W. B. Joyner and D. M. Boore. Peak horizontal acceleration and velocity from strong-motion records including records from the 1979 Imperial Valley, California, earthquake. Bulletin of the Seismological Society of America, 71(6):2011-2038, Dec 1981.

C. F. Knudson. Seismic engineering program report. Circular 0717-A, U. S. Geological Survey, Seismic Engineering Branch, January-March 1975.

C. Lachet and P.-Y. Bard. Numerical and theoretical investigations on the possibilities and limitations of Nakamura's technique. Journal of the Physics of the Earth, 42:377-397, 1994.

B. Le Brun, M. Bour, H. Fabriol, P. Dominique, P. Sabourault, F. Vermeersch, C. Martin, and J. Demand. XIème Contrat de plan Etat/Région Guadeloupe relatif è la prévention du risque sismique. Réseau accéléromètrique de Pointe-à-Pitre : rapport final, synthèse des résultats acquis depuis 1994. Final report BRGM/RP-50501-FR, BRGM, France, 2001. In French.

B. Lebrun, A.-M. Duval, P.-Y. Bard, O. Monge, M. Bour, S. Vidal, and H. Fabriol. Seismic microzonation: A comparison between geotechnical and seismological approaches in Pointeà-Pitre (French West Indies). Bulletin of Earthquake Engineering, 2(1):27-50, 2004.

B. Lebrun, H. Fabriol, M. Bour, P. Dominique, and J. Demand. Réseau accéléromètrique de Pointe-à-Pitre : traitement et interprétation des données de l'année 1999. Final report BRGM/RR-40905-FR, BRGM, France, 2000. In French.

J. Lermo and F. J. Chávez-García. Site effect evaluation using spectral ratios with only one station. Bulletin of the Seismological Society of America, 83:1574-1594, 1993.

J. Lermo and F. J. Chávez-García. Site effect evaluation at Mexico City: Dominant period and relative amplification from strong motion and microtremor records. Soil Dynamics and Earthquake Engineering, 13:413-423, 1994.

P. Lussou, P. Y. Bard, F. Cotton, and Y. Fukushima. Seismic design regulation codes: Contribution of K-Net data to site effect evaluation. Journal of Earthquake Engineering, 5(1): 13-33, Jan 2001. 
C. Martin. Restructuration du réseau accélérométrique permanent des Antilles françaises. Technical Report R 37822 PR9304232013, BRGM, France, Oct 1993. In French.

C. Martin, D. Chassagneux, and P. Dominique. Nouvelle méthodologie de réalisation des microzonages sismiques - Application au microzonage de Jarry-Baie Mahault (Guadeloupe). Final report R 38053, BRGM, France, 1994a. In French.

C. Martin, D. Chassagneux, and P. Dominique. Nouvelle méthodologie de réalisation des microzonages sismiques - Application au microzonage du Lamentin (Martinique). Final report R 38031, BRGM, France, 1994b. In French.

J. A. Martinez-Cruzado. An overview of the Puerto Rico strong motion network. Seismological Research Letters, 74(2):205, Mar/Apr 2003.

J. M. Mompelat, B. Le Brun, D. Bertil, A. Bitri, C. Lembezat, T. Pirrion, P. Sabourault, and J Vinçon. Microzonage sismique des communes de Basse-Terre, Saint Claude, Gourbeyre et Baillif (Guadeloupe). Final report BRGM/RP-52190-FR, BRGM, France, 2003. In French.

O. Monge. Microzonage sismique de l'agglomération pontoise, Guadeloupe: Reconnaissances spécifiques et étude de l'aléa sismique local. Final report R 39710, BRGM, France, 1997. In French. With the collaboration of P. Mouroux and C. Martin.

O. Monge, F. Vermeersh, and C. Martin. Microzonage sismique de l'agglomération pontoise, Guadeloupe : Extension aux communes des Abymes et du Gosier et homogénéisation. Technical Report R 39213, BRGM, France, 1998. In French. With the collaboration of A. Bourrousse and M. Terrier.

D. Motazedian and G. Atkinson. Ground-motion relations for Puerto Rico. In P. Mann, editor, Special Paper 385: Active Tectonics and Seismic Hazards of Puerto Rico, the Virgin Islands, and Offshore Areas, pages 61-80. The Geological Society of America, 2005.

Y. Nakamura. A method for dynamic characteristics estimation of subsurface using microtremor on the ground surface. QR of RTR1, 30(1):25-32, 1989.

K. Sadigh, C.-Y. Chang, J. A. Egan, F. Makdisi, and R. R. Youngs. Attenuation relationships for shallow crustal earthquakes based on California strong motion data. Seismological Research Letters, 68(1):180-189, Jan/Feb 1997.

R. K. Sadigh and J. A. Egan. Updated relationships for horizontal peak ground velocity and peak ground displacement for shallow crustal earthquakes. In Proceedings of the Sixth U.S. National Conference on Earthquake Engineering, 1998. 
F. Samarcq, P. Dominique, and C. Martin. Réseau accéléromètrique des Antilles (Guadeloupe, Martinique). Final report BRGM/RR-39207-FR, BRGM, France, 1999. In French.

F. Samarcq, C. Martin, and P. Smit. Contribution of Guadeloupe accelerometer network data for local hazard assessment. In Proceedings of Eleventh European Conference on Earthquake Engineering, 1998.

F. Scherbaum, J. J. Bommer, H. Bungum, F. Cotton, and N.A. Abrahamson. Composite ground-motion models and logic-trees: Methodology, sensitivities and uncertainties. Bulletin of the Seismological Society of America, 95(5):1575-1593, 2005. doi: 10.1785/0120040229.

F. Scherbaum, F. Cotton, and P. Smit. On the use of response spectral-reference data for the selection and ranking of ground-motion models for seismic-hazard analysis in regions of moderate seismicity: The case of rock motion. Bulletin of the Seismological Society of America, 94(6):2164-2185, Dec 2004.

P. G. Somerville. Magnitude scaling of the near fault rupture directivity pulse. Physics of the Earth and Planetary Interiors, 137:201-212, 2003.

P. Spudich, W. B. Joyner, A. G. Lindh, D. M. Boore, B. M. Margaris, and J. B. Fletcher. SEA99: A revised ground motion prediction relation for use in extensional tectonic regimes. Bulletin of the Seismological Society of America, 89(5):1156-1170, Oct 1999.

J. P. Stewart, S.-J. Chiou, J. D. Bray, R. W. Graves, P. G. Somerville, and N. A. Abrahamson. Ground motion evaluation procedures for performance-based design. PEER Report 2001/09, Pacific Earthquake Engineering Research Center, College of Engineering, University of California, Berkeley, USA, Sep 2001.

J. G. Tanner and K. M. Shedlock. Seismic hazard maps of Mexico, the Caribbean, and Central and South America. Tectonophysics, 390:159-175, 2004.

T. Travasarou, J. D. Bray, and N. A. Abrahamson. Empirical attenuation relationship for Arias intensity. Earthquake Engineering and Structural Dynamics, 32:1133-1155, 2003. DOI: $10.1002 /$ eqe. 270 .

M. D. Trifunac and A. G. Brady. A study on the duration of strong earthquake ground motion. Bulletin of the Seismological Society of America, 65(3):581-626, Jun 1975.

P. Wessel and W. H. F. Smith. Free software helps map and display data. EOS Transactions $A G U, 72: 441,1991$. 
D. Westercamp and P. Andreieff. Carte géologique à l'échelle du 1/50000: Martinique avec notice explicative. BRGM, France, 1989.

R. R. Youngs, S.-J. Chiou, W. J. Silva, and J. R. Humphrey. Strong ground motion attenuation relationships for subduction zone earthquakes. Seismological Research Letters, 68(1):58-73, Jan/Feb 1997. 
Name

Pointe-à-Pitre - Ber Pointe-à-Pitre - Gen Baie Mahault Jarry Saint François - Obs Anse-Bertrand - DD Sainte-Rose - Gend Basse-Terre - Fort Route des Mamelles Marie-Galante - Obs Houëlmont Gourbeyre Saint Claude - Belfo Gosier - Saint Felix Gosier - Ecole Suza Gosier - Eucher Jarry Baie Mahault Jarry Baie Mahault Jarry Baie Mahault Baie Mahault - Cen Baie Mahault - L. C Baie Mahault — Simé Baie Mahault - Pris Pointe-à-Pitre - Inst

Pointe-à-Pitre - AD Pointe-à-Pitre - Sous Pointe-à-Pitre - Eco Pointe-à-Pitre - CCI Pointe-à-Pitre - Stac Pointe-à-Pitre - Eco Abymes - Antea Abymes - Collège R 
Name

Abymes - Glide Fon

Abymes - Glide Surf

Abymes - Aeroport

Abymes - Perrin

Terre de Haut - Mai

Terre de Haut - Fort

Belle Eau - Stade C

Sainte Anne - Lycée

Saint Barthélemy -

Saint Martin - Marig

Terre de Bas - Petit

Marie Galante - Gra

Basse Terre - Prefec

Baillif - Aerodrome

Bouillante — Ecole P

Pointe-à-Pitre - Inst

Jarry Baie Mahault

Saint François

Météo Le Moule - R

Sainte Rose - Lycée

Morne à l'Eau

Bertrand - Anse

Fort-de-France - BR

Fort-de-France - Eco

Fort-de-France - Pre

Fort-de-France - Th

Fort-de-France - Ex

Fort-de-France - Ec

Trinité - Mairie

Caravelle - Presqu'î

Sainte Anne - Gare

Diamant - Collège $d$

Diamant - Radar M

Collège de Rivière $\mathrm{Pi}$

Vauclin - Collège du

Ducos - Barrage de

Ducos - Barrage de 
Name

Fort-de-France - Ce

Fort-de-France - Ar

Fort-de-France - Ar

Fort-de-France - Col

Fort-de-France - Co

Fort-de-France - Co

Fort-de-France - Im

Lamentin - Collège

Lamentin - Collège

Lamentin - Collège

François - Collège L

Saint Joseph - Collè

Absalon - Centre Th

Gros Morne - Réser

Carbet - Piscine du

Fond Saint Denis -

Trinité - Collège Ro

Saint Pierre - Local

Saint Pierre - Centr

Lorrain - Collège du

Lorrain - Station po

Basse Pointe - Collè

Collège des Trois-Ilet

Presbytère du Marin

Diamant - Morne B

Lamentin - Aéropor

Lamentin - Zone aér

Fort-de-France - For

Trinité - Centre Ho

Saint Pierre - Camp

Sainte Marie - Anse

Massieux

Muscade

Baltus

BO4

Morne Lézard 
Table 2: Site descriptions for stations of the strong-motion network of Conseil Général de Martinique. For each station, a brief description of the geology [Westercamp and Andreieff, 1989, BRGM, 2005], geophysical data (if available), the presence or not of soil effects, the resonance frequency, whether or not topographic effects are suspected, and the soil classification are given.

\begin{tabular}{|c|c|c|c|c|c|c|}
\hline Station & Surface geology & $\begin{array}{l}\text { Geophysical } \\
\text { data }\end{array}$ & $\begin{array}{r}\text { Soil } \\
\text { effect? }\end{array}$ & $\begin{array}{l}\text { Res. freq. } \\
\qquad(\mathrm{Hz})\end{array}$ & $\begin{array}{l}\text { Topo. } \\
\text { effect? }\end{array}$ & $\begin{array}{l}\text { Site } \\
\text { class }\end{array}$ \\
\hline CGBP & $\begin{array}{l}\text { Weathered tuff } \\
(1.5 \mathrm{~m} \text { deep })\end{array}$ & & $\mathrm{Y}$ & 4.9 & & Med. soil \\
\hline CGRA & Andesites & & & & $\mathrm{Y}$ & Rock \\
\hline CGMB & Weathered tuffites & $\begin{array}{lr}V_{p}= & 300- \\
700 \mathrm{~ms}^{-1} & \text { (clay), } \\
V_{p}=600-2500 \mathrm{~ms}^{-1} \\
\text { (weathered } \quad \text { tuff), } \\
V_{p}=2500 \mathrm{~ms}^{-1} \\
\text { (sound tuff) }\end{array}$ & & & & $?$ \\
\hline CGOB & Massive andesites & & & & $\mathrm{Y}$ & Rock \\
\hline CGDD & $\begin{array}{l}\text { Conglomerates }(7 \mathrm{~m} \\
\text { deep) on weathered } \\
\text { tuffite }\end{array}$ & & & & & Rock \\
\hline CGAS & $\begin{array}{l}\text { Very thin layer of al- } \\
\text { luvium ( } 1 \mathrm{~m} \text { deep) on } \\
\text { massive andesites }\end{array}$ & & $\mathrm{Y}$ & 11.5 & & Rock \\
\hline CGAB & $\begin{array}{l}\text { Thin layer of pumices } \\
(1-3 \mathrm{~m} \text { deep }) \text { on al- } \\
\text { tered andesites }\end{array}$ & & & & & Rock \\
\hline CGCO & Conglomerates & & & & & Rock \\
\hline CGAT & $\begin{array}{lr}\text { Modern } & \text { alluvia } \\
\text { (clays and sands, } \\
10 \mathrm{~m} \text { deep) on } \\
\text { tuffites }\end{array}$ & $V_{s}=150-200 \mathrm{~ms}^{-1}$ & $\mathrm{Y}$ & $2.2-2.7$ & & Soft soil \\
\hline CGDB & $\begin{array}{l}\text { Colluvia (clays, 8- } \\
10 \mathrm{~m}) \text { on clayey tuff } \\
(10 \mathrm{~m} \text { thick }) \text { on sound } \\
\text { tuff }\end{array}$ & & $\mathrm{Y}$ & $1.5-3.5$ & & Soft soil \\
\hline CGFR & $\begin{array}{l}\text { Colluvia (soft clay, 1- } \\
3 \mathrm{~m} \text { deep) on weath- } \\
\text { ered tuff until } 22 \mathrm{~m}\end{array}$ & $V_{s}=50-150 \mathrm{~ms}^{-1}$ & & & & $?$ \\
\hline CGDT & $\begin{array}{l}\text { Clays ( } 10 \mathrm{~m} \text { deep) on } \\
\text { massive basalt }\end{array}$ & & $\mathrm{Y}$ & $1.5-2.2$ & $\mathrm{Y}$ & Soft soil \\
\hline
\end{tabular}


Table 2: continued

\begin{tabular}{|c|c|c|c|c|c|c|}
\hline Station & Surface geology & $\begin{array}{l}\text { Geophysical } \\
\text { data }\end{array}$ & $\begin{array}{r}\text { Soil } \\
\text { effect? }\end{array}$ & $\begin{array}{l}\text { Res. freq. } \\
\qquad(\mathrm{Hz})\end{array}$ & $\begin{array}{l}\text { Topo. } \\
\text { effect? }\end{array}$ & $\begin{array}{l}\text { Site } \\
\text { class }\end{array}$ \\
\hline CGPB & $\begin{array}{l}\text { Compact clay }(3 \mathrm{~m} \\
\text { deep }) \text { on weathered } \\
\text { tuff until } 20 \mathrm{~m}\end{array}$ & & $\mathrm{Y}$ & 2.5 & & Soft soil \\
\hline CGPA & $\begin{array}{l}\text { Clays ( } 4 \mathrm{~m} \text { deep) on } \\
\text { breccias. Weathered } \\
\text { conglomerate at } 12 \mathrm{~m}\end{array}$ & & $\mathrm{Y}$ & 1.9 & & Soft soil \\
\hline CGVI & $\begin{array}{l}\text { Sands and sandy } \\
\text { clays }\end{array}$ & & $\mathrm{Y}$ & $0.9-2.1$ & & Med. soil \\
\hline CGLO & $\begin{array}{l}\text { Clays on massive an- } \\
\text { desites }\end{array}$ & & $\mathrm{Y}$ & $4-6$ & & Med./stiff soil \\
\hline CGRP & Conglomerates & & & & $\mathrm{Y}$ & $?$ \\
\hline CGSJ & $\begin{array}{l}\text { Succession of com- } \\
\text { pact clays and clayey } \\
\text { tuffs }\end{array}$ & & $\mathrm{Y}$ & 2.2 & & Med. soil \\
\hline CGTR & $\begin{array}{l}\text { Soft sandy clays } \\
\text { ( } 15 \mathrm{~m} \text { deep) on very } \\
\text { weathered andesites }\end{array}$ & & $\mathrm{Y}$ & 1.6 & & V. soft soil \\
\hline CGSA & Colluvia & $V_{s}=150-400 \mathrm{~ms}^{-1}$ & $\mathrm{Y}$ & 3 & & V. soft soil \\
\hline CGCA & Conglomerates & & & & & Rock \\
\hline CGDI & $\begin{array}{l}\text { Colluvia on pyroclas- } \\
\text { tic breccias }\end{array}$ & & & & & Rock \\
\hline CGVA & $\begin{array}{l}\text { Modern alluvia }(3 \mathrm{~m} \\
\text { deep) on soft rocky } \\
\text { tuff }\end{array}$ & $V_{s}=150-300 \mathrm{~ms}^{-1}$ & $\mathrm{Y}$ & $3-4$ & & Soft soil \\
\hline $\begin{array}{l}\text { CGLR } \\
\& \\
\text { CGCP }\end{array}$ & $\begin{array}{l}\text { Pumices and modern } \\
\text { alluvia }\end{array}$ & $V_{s}=150-400 \mathrm{~ms}^{-1}$ & $?$ & $1.5-1.7 ?$ & & $?$ \\
\hline
\end{tabular}




\section{List of Figures}

1 The location of the strong-motion stations that have operated (unfilled symbols and names in brackets), or are still operating (filled symbols), on Guadeloupe and Martinique. Also shown are the five stations of the BRGM broadband network at Bouillante. Note that the nine stations of the original BRGM network that operated between 1977 and 1993 are not shown. Also two other stations: SBTA and SMMA are not shown since they are on Saint Bathélemy and Saint Martin respectively, which are outside the area covered by the maps. . . . . . .

$2 \quad \mathrm{H} / \mathrm{V}$ spectral ratios for the stations with strong site effects. The thick continuous line represents the average spectral ratio and the dotted lines indicate the average spectral ratio \pm 1 standard deviation. . . . . . . . . . . . .

$3 \mathrm{H} / \mathrm{V}$ spectral ratios for the stations characterized by a site effect but where the result needs to be confirmed. The thick continuous line represents the average spectral ratio and the dotted lines indicate the average spectral ratio \pm 1 standard deviation. . . . . . . . . . . . . . . . . . . . .

4 The $\mathrm{H} / \mathrm{V}$ spectral ratios for the station CGCA on rock and for the station CGRA on rock but with a suspected topographic effect. The thick continuous line represents the average spectral ratio and the dotted lines indicate the average spectral ratio \pm 1 standard deviation. . . . . . . . . . . . . . . . . .

5 Map showing the locations, focal mechanisms and magnitudes of those earthquakes whose data has been used for this study. Also shown are the location of the strong-motion stations that have operated, or are still operating, on Guadeloupe and Martinique and the five broadband stations at Bouillante. . . . . . .

6 Distribution in terms of magnitude, hypocentral distance, focal depth and earthquake type of the data recorded on Guadeloupe and Martinique of the largest earthquakes. All earthquakes have a moment magnitude given by Harvard CMT. The number of records within each focal depth class and earthquake type are given in the legend. . . . . . . . . . . . . . . . . . . .

$7 \quad$ Normalized residuals for PGA for the equation of Ambraseys et al. [2005] with respect to epicentral distance and $M_{w} \ldots \ldots \ldots \ldots \ldots \ldots$

8 Response spectral acceleration ratios (adjusted to account for minor differences in magnitude and distance using the equations of Ambraseys et al. [2005]) for the common stations that recorded events of similar size and at similar locations. Epicentral distances for the events are given in brackets after the station name. 
9 Normalized residuals for PGA for the equation of Youngs et al. [1997] with respect to hypocentral distance and $M_{w}$. Dots and crosses are for intraslab and interface events respectively. . . . . . . . . . . . . . . . . . . . . . . 42

10 Acceleration time-histories from the station TDBA of the 14th Feb. 2005 18:06

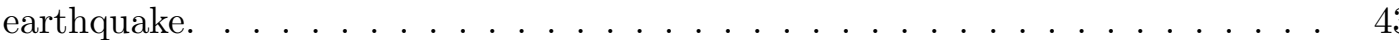

11 Comparison between the $5 \%$ elastic acceleration response spectra for two horizontal time-histories recorded at TDBA of the 14th Feb. 2005 18:06 earthquake and the spectrum predicted by the ground-motion model of Ambraseys et al. [2005], which was derived for the larger horizontal component. . . . . . . . . . . 44 
Figure 1: The location of the strong-motion stations that have operated (unfilled symbols and names in brackets), or are still operating (filled symbols), on Guadeloupe and Martinique. Also shown are the five stations of the BRGM broadband network at Bouillante. Note that the nine stations of the original BRGM network that operated between 1977 and 1993 are not shown. Also two other stations: SBTA and SMMA are not shown since they are on Saint Bathélemy and Saint Martin respectively, which are outside the area covered by the maps. 
Figure 2: $\mathrm{H} / \mathrm{V}$ spectral ratios for the stations with strong site effects. The thick continuous line represents the average spectral ratio and the dotted lines indicate the average spectral ratio \pm 1 standard deviation. 
Figure 3: H/V spectral ratios for the stations characterized by a site effect but where the result needs to be confirmed. The thick continuous line represents the average spectral ratio and the dotted lines indicate the average spectral ratio \pm 1 standard deviation. 
Figure 4: The H/V spectral ratios for the station CGCA on rock and for the station CGRA on rock but with a suspected topographic effect. The thick continuous line represents the average spectral ratio and the dotted lines indicate the average spectral ratio \pm 1 standard deviation. 
Figure 5: Map showing the locations, focal mechanisms and magnitudes of those earthquakes whose data has been used for this study. Also shown are the location of the strong-motion stations that have operated, or are still operating, on Guadeloupe and Martinique and the five broadband stations at Bouillante. 
Figure 6: Distribution in terms of magnitude, hypocentral distance, focal depth and earthquake type of the data recorded on Guadeloupe and Martinique of the largest earthquakes. All earthquakes have a moment magnitude given by Harvard CMT. The number of records within each focal depth class and earthquake type are given in the legend. 
Figure 7: Normalized residuals for PGA for the equation of Ambraseys et al. [2005] with respect to epicentral distance and $M_{w}$. 
(a) For the aftershocks of 13:37 $\left(M_{w} 5.3\right)$ and 18:53 $\left(M_{w} 5.4\right)$ on 21st Nov. 2004

(b) For the aftershocks of 27th Nov. 2004 23:44 $\left(M_{w} 4.9\right)$ and 2nd Dec. 2004 14:47 $\left(M_{w} 5.0\right)$

Figure 8: Response spectral acceleration ratios (adjusted to account for minor differences in magnitude and distance using the equations of Ambraseys et al. [2005]) for the common stations that recorded events of similar size and at similar locations. Epicentral distances for the events are given in brackets after the station name. 
Figure 9: Normalized residuals for PGA for the equation of Youngs et al. [1997] with respect to hypocentral distance and $M_{w}$. Dots and crosses are for intraslab and interface events respectively. 
Figure 10: Acceleration time-histories from the station TDBA of the 14th Feb. 2005 18:06 earthquake. 
Figure 11: Comparison between the 5\% elastic acceleration response spectra for two horizontal time-histories recorded at TDBA of the 14th Feb. 2005 18:06 earthquake and the spectrum predicted by the ground-motion model of Ambraseys et al. [2005], which was derived for the larger horizontal component. 


\section{List of Tables}

1 Information on strong-motion stations that have operated, or are still operating, on Guadeloupe and Martinique and whose data has been used in this article. Also listed are those broadband stations operated by BRGM at Bouillante. CGM is Conseil Général de Martinique, RAP-OVSG is Observatoire Volcanologique et Sismologique de Guadeloupe (IPGP), RAP-OVSM is Observatoire Volcanologique et Sismologique de la Martinique (IPGP), BRGM LB is the broadband network operated by BRGM, B is in a structural-related station, $\mathrm{H}$ is a hill site (topographic effects suspected), $\mathrm{R}$ is rock and $\mathrm{S}$ is soil. . . . . . 27

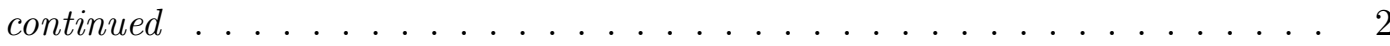

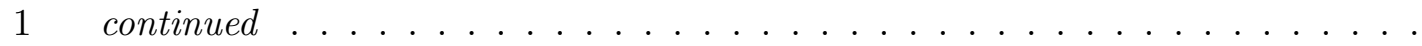

2 Site descriptions for stations of the strong-motion network of Conseil Général de Martinique. For each station, a brief description of the geology [Westercamp and Andreieff, 1989, BRGM, 2005], geophysical data (if available), the presence or not of soil effects, the resonance frequency, whether or not topographic effects are suspected, and the soil classification are given. . . . . . . . . . . . . . . . 30

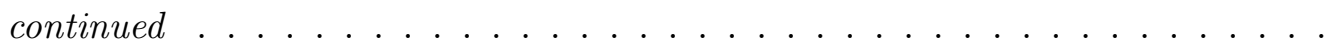

3 Earthquakes with $M_{w}$ values from Harvard CMT recorded by the RAP, BRGM, CDSA and CGM strong-motion networks operating on Guadeloupe and Martinique.

4 Ranking of different ground-motion estimation equations for modelling the entire Antilles shallow crustal earthquake ground motion dataset. MEDLH is the median LH value (see text), MEDNR is the median normalized residual, MEANNR is the mean normalized residual and STDNR is the standard deviation of the normalized residuals. . . . . . . . . . . . . . . . . . .

$5 \quad$ Ranking of different ground-motion estimation equations for modelling the entire Antilles subduction earthquake ground motion dataset. MEDLH is the median LH value (see text), MEDNR is the median normalized residual, MEANNR is the mean normalized residual and STDNR is the standard deviation of the normalized residuals. . . . . . . . . . . . . . . . . . .

6 Observed and estimated strong-motion parameters of horizontal components of the record from TDBA of the 14th Feb. 2005 18:06 earthquake. . . . . . . . . . 
Table 3: Earthquakes with $M_{w}$ values from Harvard CMT recorded by the RAP, BRGM, CDSA and CGM strong-motion networks operating on Guadeloupe and Martinique.

\begin{tabular}{lllrlrrr}
\hline Date & $\begin{array}{l}\text { Time } \\
(\mathrm{UTC})\end{array}$ & $M_{w}$ & $\begin{array}{r}\text { Depth } \\
(\mathrm{km})\end{array}$ & $\begin{array}{l}\text { Type and } \\
\text { mechanism }\end{array}$ & $\begin{array}{r}\text { Number of } \\
\text { records }\end{array}$ & $\begin{array}{r}d_{h} \text { range } \\
(\mathrm{km})\end{array}$ & $\begin{array}{r}\text { PGA range } \\
\left(\mathrm{ms}^{-2}\right)\end{array}$ \\
\hline $24 / 09 / 1996$ & $11: 42$ & 5.6 & 139 & Intraslab & 4 & $157-182$ & $0.05-0.08$ \\
$25 / 06 / 1998$ & $21: 03$ & 5.6 & 30 & Interface & 4 & $149-154$ & $0.02-0.03$ \\
$08 / 06 / 1999$ & $12: 04$ & 5.8 & 31 & Interface & 19 & $73-187$ & $0.01-1.28$ \\
$11 / 07 / 1999$ & $11: 51$ & 5.2 & 31 & Crustal (strike-slip) & 7 & $188-193$ & $0.02-0.04$ \\
$28 / 08 / 1999$ & $04: 27$ & 5.4 & 30 & Interface & 16 & $89-101$ & $0.03-0.13$ \\
$20 / 12 / 1999$ & $10: 43$ & 5.3 & 29 & Interface & 15 & $112-120$ & $0.03-0.16$ \\
$16 / 02 / 2000$ & $07: 03$ & 5.3 & 0 & Interface & 2 & $116-117$ & $0.004-0.004$ \\
$23 / 02 / 2000$ & $19: 20$ & 5.4 & 34 & Interface & 3 & $153-156$ & $0.01-0.01$ \\
$27 / 10 / 2000$ & $19: 02$ & 5.6 & 30 & Interface & 9 & $144-155$ & $0.02-0.10$ \\
$30 / 10 / 2000$ & $03: 07$ & 5.8 & 33 & Interface & 9 & $129-140$ & $0.03-0.19$ \\
$05 / 01 / 2001$ & $08: 06$ & 5.7 & 20 & Crustal (strike-slip) & 12 & $73-157$ & $0.02-0.42$ \\
$05 / 04 / 2001$ & $13: 54$ & 5.1 & 47 & Intraslab & 17 & $89-168$ & $0.02-0.20$ \\
$25 / 09 / 2001$ & $23: 16$ & 5.4 & 27 & Interface & 6 & $90-258$ & $0.02-0.42$ \\
$07 / 12 / 2001$ & $15: 59$ & 5.1 & 22 & Interface & 3 & $103-251$ & $0.01-0.08$ \\
$14 / 05 / 2003$ & $06: 03$ & 6.6 & 48 & Crustal (strike-slip) & 35 & $363-497$ & $0.02-0.34$ \\
$30 / 06 / 2003$ & $00: 07$ & 5.7 & 30 & Crustal (odd) & 12 & $227-426$ & $0.002-0.15$ \\
$01 / 03 / 2004$ & $06: 12$ & 4.8 & 43 & Intraslab & 35 & $67-180$ & $0.01-0.88$ \\
$30 / 03 / 2004$ & $16: 23$ & 4.9 & 70 & Interface & 5 & $158-347$ & $0.002-0.02$ \\
$21 / 11 / 2004$ & $11: 41$ & 6.3 & 13 & Crustal (normal) & 37 & $27-158$ & $0.02-2.09$ \\
$21 / 11 / 2004$ & $13: 37$ & 5.3 & 19 & Crustal (normal) & 17 & $36-148$ & $0.02-0.16$ \\
$21 / 11 / 2004$ & $18: 53$ & 5.4 & 13 & Crustal (normal) & 13 & $27-154$ & $0.01-1.33$ \\
$27 / 11 / 2004$ & $23: 44$ & 4.9 & 13 & Crustal (normal) & 23 & $26-145$ & $0.004-0.17$ \\
$02 / 12 / 2004$ & $14: 47$ & 5.0 & 14 & Crustal (normal) & 16 & $35-120$ & $0.002-0.08$ \\
$14 / 02 / 2005$ & $18: 06$ & 5.8 & 12 & Crustal (normal) & 17 & $14-144$ & $0.09-6.94$ \\
\hline & & & & & & &
\end{tabular}

$M_{w}$ estimates have been taken from the Harvard CMT catalogue and times and locations from the IPGP catalogue except for those earthquakes not in this catalogue, for which the ISC catalogue has been used. The mechanism classification scheme of Frohlich and Apperson [1992] based on the plunges of the moment tensor eigenvectors ( $\mathrm{T}, \mathrm{B}$ and $\mathrm{P}$ axes) has been used. In this classification scheme earthquakes with $\mathrm{T}$-axis plunges greater than $50^{\circ}$ are classified as thrust, earthquakes with $\mathrm{B}$-axis plunges greater than $60^{\circ}$ are classified as strike-slip, earthquakes with $\mathrm{P}$-axis plunges greater than $60^{\circ}$ are classified as normal and all other earthquakes are classified as odd (roughly corresponding to earthquakes classified as oblique by other classification procedures). Only data from ground response instruments are listed here. One record refers to three mutually perpendicular components. 
Table 4: Ranking of different ground-motion estimation equations for modelling the entire Antilles shallow crustal earthquake ground motion dataset. MEDLH is the median LH value (see text), MEDNR is the median normalized residual, MEANNR is the mean normalized residual and STDNR is the standard deviation of the normalized residuals.

\begin{tabular}{lcrrrr}
\hline Model & Rank & MEDLH & MEDNR & MEANNR & STDNR \\
\hline Abrahamson and Silva [1997] & D & 0.037 & -1.484 & -1.471 & 1.610 \\
Ambraseys et al. [2005] & C & 0.217 & -0.286 & -0.341 & 1.304 \\
Berge-Thierry et al. [2003] & D & 0.098 & -0.815 & -0.877 & 1.546 \\
Boore et al. [1997] & D & 0.001 & -2.323 & -2.434 & 2.210 \\
Campbell and Bozorgnia [2003] & D & 0.004 & -1.795 & -1.868 & 2.341 \\
Motazedian and Atkinson [2005] & D & 0.002 & -2.520 & -1.981 & 2.495 \\
Lussou et al. [2001] & D & 0.151 & 0.092 & 0.177 & 1.556 \\
Sadigh et al. [1997] & D & 0.013 & -0.557 & -0.614 & 2.538 \\
Spudich et al. [1999] & D & 0.015 & -1.114 & -1.326 & 2.181 \\
\hline
\end{tabular}


Table 5: Ranking of different ground-motion estimation equations for modelling the entire Antilles subduction earthquake ground motion dataset. MEDLH is the median LH value (see text), MEDNR is the median normalized residual, MEANNR is the mean normalized residual and STDNR is the standard deviation of the normalized residuals.

\begin{tabular}{lcrrrr}
\hline Model & Rank & MEDLH & MEDNR & MEANNR & STDNR \\
\hline Atkinson and Boore [2003] & $\mathrm{D}$ & 0.003 & 2.650 & 2.715 & 1.439 \\
Crouse [1991] & $\mathrm{D}$ & 0.007 & -2.388 & -2.360 & 1.406 \\
Youngs et al. [1997] & $\mathrm{B}$ & 0.362 & -0.501 & -0.508 & 0.881 \\
\hline
\end{tabular}


Table 6: Observed and estimated strong-motion parameters of horizontal components of the record from TDBA of the 14th Feb. 2005 18:06 earthquake.

\begin{tabular}{lrrrrr}
\hline & $\begin{array}{r}\text { PGA } \\
(\mathrm{g})\end{array}$ & $\begin{array}{r}\text { PGV } \\
\left(\mathrm{cms}^{-1}\right)\end{array}$ & $\begin{array}{r}\text { PGD } \\
(\mathrm{cm})\end{array}$ & $\begin{array}{r}\text { AI } \\
\left(\mathrm{ms}^{-1}\right)\end{array}$ & $\begin{array}{r}\text { RSD } \\
(\mathrm{s})\end{array}$ \\
\hline Observed & 0.71 & 26.0 & 2.8 & 2.52 & 5.3 \\
Estimated & 0.16 & 7.1 & 1.1 & 0.10 & 5.5 \\
Observed/estimated & 4.44 & 3.7 & 2.5 & 25.20 & 1.0 \\
\hline
\end{tabular}

where PGA is peak ground acceleration of the larger horizontal component, PGV is peak ground velocity (geometric mean), PGD is peak ground displacement (geometric mean), AI is Arias intensity (arithmetic mean) and RSD is relative significant duration (arithmetic mean), defined as the interval between the first exceedence of 5 and $95 \%$ of total Arias intensity [Trifunac and Brady, 1975]. Estimated PGA is from the model of Ambraseys et al. [2005], estimated PGV is from the model of Campbell [1997], estimated PGD is from the model of Sadigh and Egan [1998], estimated AI is from the model of Travasarou et al. [2003] and estimated RSD is from the model of Abrahamson and Silva [1996]. 